\title{
PENYERAPAN KARBON PADA BUDIDAYA RUMPUT LAUT Kappaphycus alvarezii dan Gracilaria gigas DI PERAIRAN TELUK GERUPUK, LOMBOK TENGAH, NUSA TENGGARA BARAT
}

\author{
Erlania"), Kukuh Nirmala**), dan Dinar Tri Soelistyowati"*) \\ *) Pusat Penelitian dan Pengembangan Perikanan Budidaya \\ Jl. Ragunan 20, Pasar Minggu, Jakarta Selatan 12540 \\ E-mail:erlania_elleen@yahoo.com \\ **) Institut Pertanian Bogor \\ Jl. Agatis, Kampus IPB Darmaga, Bogor 16680
}

(Naskah diterima: 25 Maret 2013; Disetujui publikasi: 18 Mei 2013)

\begin{abstract}
ABSTRAK
Pengikatan karbon oleh algae fotoautotrofik berpotensi untuk mengurangi pelepasan $\mathrm{CO}_{2}$ ke atmosfer dan dapat membantu mencegah percepatan terjadinya pemanasan global. Penelitian ini bertujuan untuk menganalisis tingkat penyerapan karbon pada budidaya rumput laut Kappaphycus alvarezii dan Gracilaria gigas berdasarkan aktivitas fotosintesis serta variabel-variabel yang mempengaruhinya. Budidaya rumput laut dilakukan dengan metode long-line di perairan Teluk Gerupuk, Lombok Tengah pada satu unit long-line dengan luas area $1.250 \mathrm{~m}^{2}$. Selama penelitian, dilakukan pengujian terhadap sampel rumput laut dan sampel air laut dari lokasi budidaya yang diambil pada hari ke-0, 10, 20, 30, dan 45 pemeliharaan. Laju penyerapan karbon total berdasarkan biomassa panen pada G. gigas hampir 300\% lebih tinggi dibandingkan K. alvarezii. Selain itu, laju pertumbuhan dan produksi karbohidrat pada G. gigas juga lebih tinggi, yang mengindikasikan laju fotosintesis yang lebih tinggi, dan didukung oleh indeks percabangan yang juga lebih tinggi. Potensi penyerapan karbon di perairan Teluk Gerupuk mencapai 6.656,51 ton C/tahun untuk budidaya K. Alvarezii dan 19.339,02 ton $\mathrm{C} /$ tahun untuk budidaya G. gigas. Penyerapan karbon berhubungan dengan kandungan pigmen dan laju pertumbuhan rumput laut, serta konsentrasi $\mathrm{CO}_{2}$ dan kecerahan perairan.
\end{abstract}

KATA KUNCl: penyerapan karbon, budidaya rumput laut, Kappaphycus alvarezii, Gracilaria gigas, Teluk Gerupuk

ABSTRACT: Carbon absorption in seaweeds aquaculture Kappaphycus alvarezii and Gracilaria gigas in Gerupuk Bay, Central Lombok, West Nusa Tenggara. By: Erlania, Kukuh Nirmala, and Dinar Tri Soelistyowati

Carbon sequest ration by photoautotrophic algae is potential to reduce $\mathrm{CO}_{2}$ released to the atmosphere, and support to reduce the inclination of global warming. The aim of this study was to analyze the level of carbon sequestration by seaweed aquaculture of Kappaphycus alvarezii and Gracilaria gigas. Seaweeds cultivation was conducted at Gerupuk Bay, Central Lombok with long-line culture system for wide area of 1,250 $\mathrm{m}^{2}$. The seaweeds and sea water parameters were analysed on days-0,10,20,30, and 45 days of culture. Total rate of carbon sequestration based on biomass of seaweeds harvesting at the end of cultivation showed that G. gigas was almost 300\% higher than that $\mathrm{K}$. alvarezii, and also higher daily growth rate, carbohydrates production, and photosynthesis rate that supported by higher branching index. Potency of carbon 
sequestration in Gerupuk Bay area reached 6,656.51 tons C/year for K. alvarezii and 19,339.02 tons C/year for G. gigas cultivation. The rate of carbon absorption was directly related to pigments content and seaweed growth rates, as well as environmental parameters that was concentration of $\mathrm{CO}_{2}$ and water transparency.

KEYWORDS: carbon absorption, seaweed aquaculture, Kappaphycus alvarezii, Gracilaria gigas, Gerupuk Bay

\section{PENDAHULUAN}

Laju peningkatan tahunan dari konsentrasi $\mathrm{CO}_{2}$ di atmosfir secara global semakin besar dalam kurun waktu 10 tahun terakhir (19952005) yaitu rata-rata $1,9 \mathrm{mg} / \mathrm{L}$ per tahun (IPCC, 2007). Terjadinya peningkatan emisi gas $\mathrm{CO}_{2}$ dan gas rumah kaca (green house gas/GHG) lainnya ke atmosfir secara terus-menerus telah berkontribusi pada terjadinya perubahan iklim (Nellemann et al., 2009). Faktor yang menjadi pemicu terjadinya perubahan iklim dapat berupa faktor alamiah maupun aktivitas manusia (antropogenik) yang menyebabkan peningkatan emisi GHG ke atmosfir yang berdampak pada terjadinya kenaikan suhu permukaan bumi. Saat ini, perikanan budidaya diposisikan sebagai salah satu subsektor yang ikut berkontribusi terhadap peningkatan GHG $\mathrm{CO}_{2}$ di atmosfir. Berbagai langkah mitigasi terhadap perubahan iklim telah dilakukan, termasuk oleh Kementerian Kelautan dan Perikanan, di antaranya adalah penanaman vegetasi pantai yang dapat mengurangi konsentrasi $\mathrm{CO}_{2}$ diatmosfer (Aldrian et al., 2011 ). Sejauh ini upaya mitigasi yang umumnya dilakukan lebih cenderung berbasis ekosistem (ecosystem based).

Rumput laut merupakan salah satu komoditas yang menjadi prioritas terkait Program Industrialisasi Kelautan dan Perikanan untuk mencapai peningkatan produksi perikanan nasional. Pada tahun 2011 produksi rumput laut telah menyumbang $60 \%$ dari total produksi perikanan budidaya (KKP, 2011 ). Jenis rumput laut yang menjadi komoditas unggulan untuk pencapaian target produksi tersebut terutama adalah Eucheuma cottonii yang secara taksonomi telah diubah namanya menjadi Kappaphycus alvarezii karena tipe substansi yang dihasilkan berupa kappa-karaginan. $K$. alvarezii termasuk salah satu jenis utama dari komoditas ekspor rumput laut Indonesia sebagai penghasil karaginan (karaginofit).

Pengikatan karbon oleh algae fotoautotrofik berpotensi untuk mengurangi pelepasan
$\mathrm{CO}_{2}$ ke atmosfer dan dapat membantu mengurangi kecenderungan terjadinya pemanasan global (Kaladharan et al., 2009). Rumput laut atau makroalgae termasuk salah satu vegetasi pantai yang merupakan penyerap karbon yang sangat baik jika dibandingkan dengan tumbuhan terestrial. Untuk pertumbuhan dan perkembangannya, rumput laut melakukan proses fotosintesis dengan memanfaatkan $\mathrm{CO}_{2}$ dan energi cahaya yang dikonversi menjadi karbohidrat. Meskipun faktor-faktor yang dibutuhkan untuk pertumbuhan rumput laut tergolong sederhana (nutrien, trace mineral, air $\mathrm{CO}_{2}$, dan cahaya matahari) dan relatif sama dengan tumbuhan terestrial, namun kelompok algae ini dapat memanfaatkannya dengan sangat efisien sehingga menghasilkan produktivitas yang tinggi (Packer, 2009).

Aktivitas marikultur pada skala besar, khususnya untuk spesies rumput laut ekonomis penting, secara global dapat menurunkan konsentrasi $\mathrm{CO}_{2}$ di atmosfir dan juga menghasilkan biomassa untuk bahan baku industri fikokoloid dari rumput laut (Kaladharan et al., 2009). Oleh karena itu, budidaya rumput laut sangat baik dikembangkan untuk tujuan produksi dan sebagai agen penyerap karbon. Dengan demikian, sektor kelautan dan perikanan juga dapat memberikan kontribusi positif dalam upaya mitigasi perubahan iklim melalui kegiatan budidaya (culture based).

Penelitian ini dilakukan untuk menganalisis tingkat penyerapan karbon pada budidaya rumput laut berdasarkan aktivitas fotosintesis serta variabel-variabel yang mempengaruhinya. Jenis rumput laut yang digunakan pada penelitian ini adalah Kappaphycus alvarezii yang menjadi komoditas unggulan budidaya di laut sebagai penghasil karaginan (karaginofit) dan Gracilaria gigas yang merupakan salah satu spesies rumput laut yang umumnya dibudidayakan di tambak sebagai penghasil agar (agarofit). Penelitian ini diharapkan memberikan informasi potensi rumput laut sebagai penyerap karbon serta prospek pengembangan budidaya rumput laut yang berke- 
lanjutan sebagai upaya pengendalian GHG $\mathrm{CO}_{2}$, dan secara tidak langsung berperan dalam proses mitigasi perubahan iklim.

\section{BAHAN DAN METODE}

Penelitian telah dilaksanakan di perairan Teluk Gerupuk, Kabupaten Lombok Tengah, Provinsi Nusa Tenggara Barat. Jangka waktu pelaksanaan penelitian terdiri atas satu siklus budidaya rumput laut (satu siklus 45 hari), yang telah dilaksanakan pada awal musim tanam di lokasi tersebut, yaitu pada bulan JuliAgustus 2012. Bibit rumput laut yang digunakan dalam penelitian ini adalah jenis Kappaphycus alvarezii strain Maumere yang berasal dari National Seaweed Center, Balai Budidaya Laut, Lombok yang berlokasi di perairan Teluk Gerupuk, Kabupaten Lombok Tengah; dan Gracilaria gigas yang berasal dari tambak budidaya rumput laut milik pembudidaya di Desa Sekotong Barat, Kabupaten Lombok Barat. Selama penelitian dilakukan pengujian sampel rumput laut dan sampel air laut dari lokasi budidaya yang diambil pada hari ke-0, 10, 20, 30, dan 45 pemeliharaan. Penelitian dilaksanakan menggunakan rancangan acak lengkap (RAL) satu faktor. Faktor perlakuan terdiri atas dua taraf yaitu dua spesies rumput laut yang berbeda (K. alvarezii dan G. gigas), dengan lima ulangan. Ulangan yang dilakukan berupa ulangan sampling, yaitu dengan pengambilan sampel rumput laut pada lima titik tanam.

Budidaya rumput laut dilakukan dengan metode rawai (long-line). Bobot awal rumput laut yang ditanam yaitu sekitar 100 gram per titik tanam. Budidaya rumput laut dilakukan pada satu unit long-line dengan ukuran $50 \mathrm{~m} \mathrm{x}$ $50 \mathrm{~m}$, yang terdiri atas 24 ris (12 ris untuk $K$. alvarezii dan 12 ris untuk G. gigas). Jarak antar titik tanam/ikatan bibit pada tali ris adalah 20 $\mathrm{cm}$ (satu ris terdiri atas 250 titik tanam), dan jarak antar tali ris masing-masing $2 \mathrm{~m}$. Budidaya rumput laut dilakukan selama satu siklus, di mana masa pemeliharaan untuk satu siklus $K$. alvarezii adalah 45 hari berdasarkan SNI 7579.2:2010; yang juga sesuai dengan kebiasaan masyarakat pembudidaya rumput laut di lokasi tersebut. Sedangkan masa pemeliharaan G. gigas untuk satu siklus yaitu 30 hari sebagaimana siklus budidaya yang umum dilakukan di tambak.

Pengambilan sampel rumput laut dilakukan secara acak sebanyak lima titik tanam, yang dilakukan dengan metode sampling-panen.
Pertumbuhan diamati dengan melakukan penimbangan bobot basah tanaman dari setiap titik tanam yang terambil sebagai sampel, selanjutnya dikeringkan untuk dilakukan analisis laboratorium. Parameter yang dianalisis terdiri atas kandungan total karbon organik (selanjutnya disebut sebagai total karbon), karbohidrat, klorofil-a, dan fikoeritrin rumput laut; serta parameter lingkungan yang terdiri atas suhu, salinitas, $\mathrm{CO}_{2}$, DO, $\mathrm{pH}$, TDS, nitrat, nitrit, amonia, fosfat, dan kecerahan perairan. Parameter uji yang diamati selama penelitian terdiri atas laju penyerapan karbon oleh rumput laut (Muraoka, 2004), laju pertumbuhan harian dan produktivitas rumput laut (Lüning, 1990), produksi karbohidrat yang dihasilkan oleh rumput laut, kandungan pigmen fotosintesis pada rumput laut (Jeffrey \& Humphrey, 1975 in Naguit \& Tisera, 2009), dan indeks percabangan (branching index) (Pickering et al., 1995), serta analisis kualitas perairan.

Data parameter penyerapan karbon yang terdiri atas laju penyerapan karbon, kandungan karbohidrat dan kandungan pigmen rumput laut dianalisis secara deskriptif untuk melihat trend dari awal hingga akhir pemeliharaan. Hubungan parameter penyerapan karbon dan parameter lingkungan perairan, dianalisis dengan metode cluster analysis dan analisis komponen utama (principal component analysis) dan analisis korelasi.

\section{HASIL DAN BAHASAN}

\section{Tingkat Penyerapan Karbon berdasar- kan Aktivitas dan Produk Fotosintesis pada Rumput Laut $K$. alvarezii dan $G$. gigas}

Kemampuan rumput laut $K$. alvarezii dan G. gigas yang dibudidaya dalam menyerap karbon dari lingkungan perairan semakin menurun dengan semakin bertambahnya umur pemeliharaan. Laju penyerapan karbon total yang diestimasi pada akhir masa budidaya berdasarkan biomassa panen pada $G$. gigas hampir mencapai 335\% K. alvarezii (Gambar 1). Hal ini juga didukung oleh laju pertumbuhan dan pertambahan bobot $G$. gigas yang juga jauh lebih tinggi pada K. alvarezii (Gambar 2). Hal ini dipengaruhi oleh morfologi G. gigas yang memiliki talus dengan diameter yang lebih kecil dan lebih panjang dibanding $K$. alvarezii, sehingga luas total permukaan talusnya juga lebih besar dibanding $K$. avarezii. Besarnya luas permukaan menyebabkan $G$. 


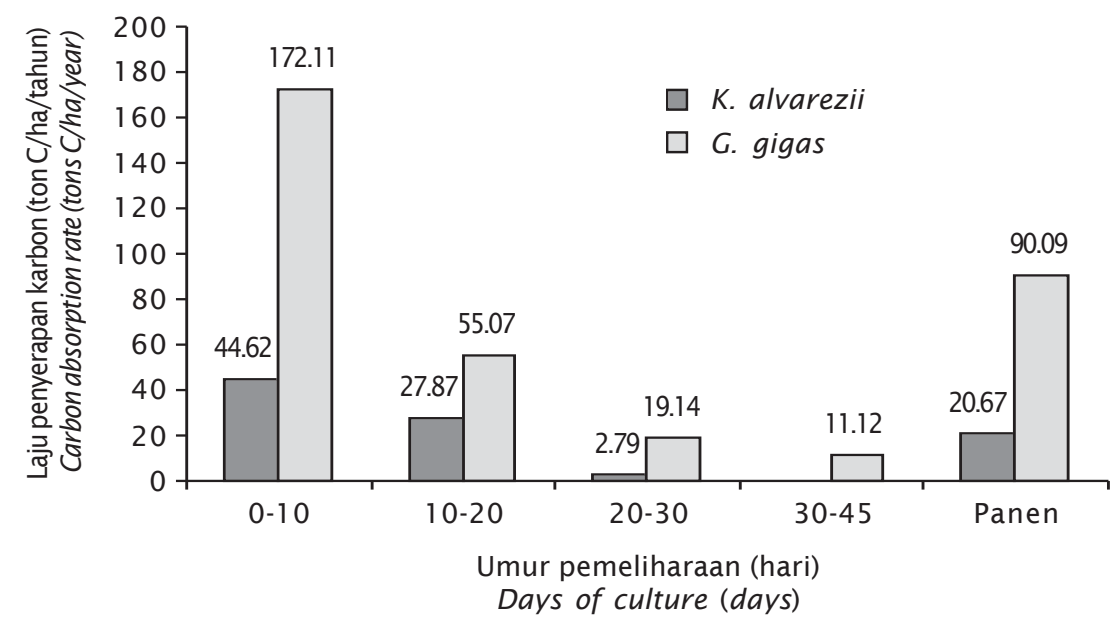

Gambar 1. Laju penyerapan karbon pada rumput laut K. alvarezii dan G. gigas

Figure 1. Carbon absorption rate of seaweeds $K$. alvarezii and G. gigas

gigas lebih efisien dalam menyerap cahaya matahari yang dibutuhkan dalam proses fotosintesis. Perbedaan morfologi ini juga ditunjukkan oleh indeks percabangan G. gigas yang jauh lebih tinggi dibandingkan K. alvarezii. Hasil penelitian Stewart \& Carpenter (2003) menunjukkan bahwa laju fotosintesis bersih dari biomassa spesifik rumput laut meningkat dengan semakin meningkatnya rasio luas permukaan: volume talus. Dalam hal ini, G. gigas memiliki talus dengan ukuran yang jauh lebih kecil dan jumlah cabang yang jauh lebih banyak dibandingkan $K$. alvarezii.
Rata-rata laju pertumbuhan harian dari $K$. alvarezii meningkat pada hari ke 0-10 dan menurun hingga akhir masa pemeliharaan (hari ke-45). Sedangkan pada G. gigas rata-rata laju pertumbuhan harian awalnya lebih tinggi, kemudian menurun pada akhir masa pemeliharaan (hari ke-30) (Gambar 2). Berdasarkan hasil penelitian Stewart \& Carpenter (2003), bahwa algae dengan struktural sederhana yang berbentuk lembaran, tipis, bercabang, dan memiliki permukaan halus/licin menunjukkan terdapatnya korelasi yang tinggi antara rasio luas permukaan:volume talus dengan laju

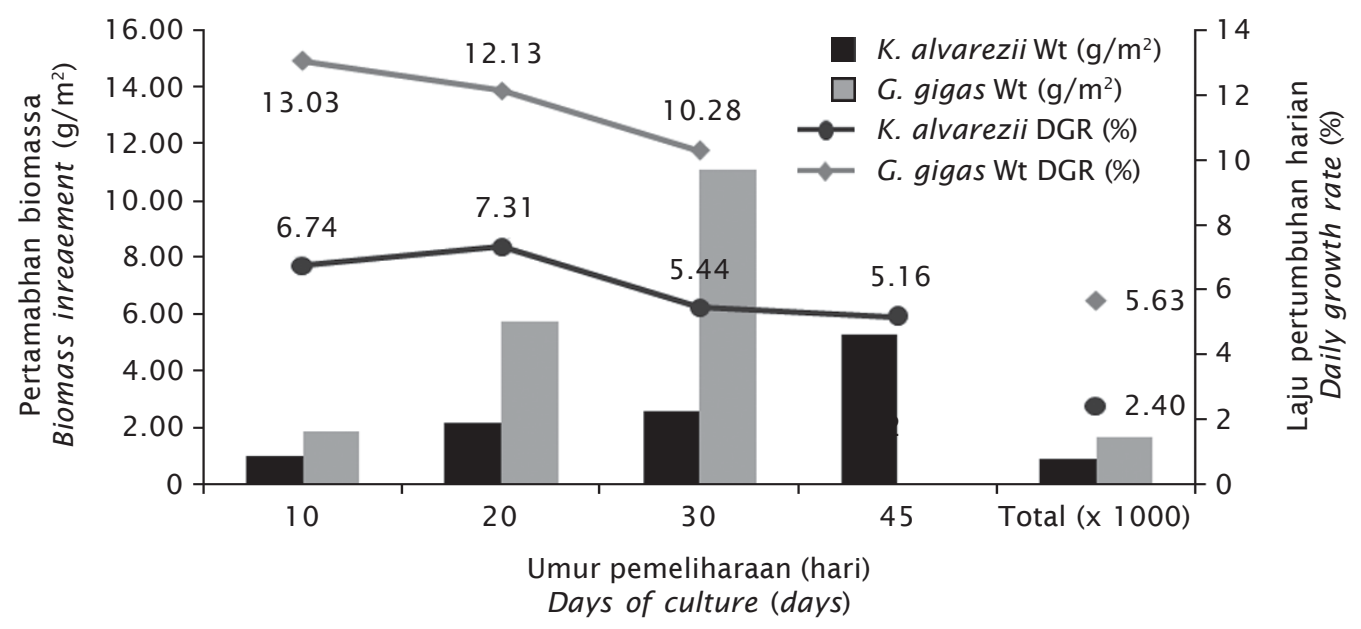

Gambar 2. Pertambahan bobot $\left(\mathrm{g} / \mathrm{m}^{2}\right)$ dan laju pertumbuhan harian (\%) K. alvarezii dan G. gigas Figure 2. Biomass increasement $\left(\mathrm{g} / \mathrm{m}^{2}\right)$ and daily growth rate (\%) of $\mathrm{K}$. alvarezii and G. gigas 
pertumbuhan dan laju fotosintesisnya, dibandingkan algae dengan talus yang lebih tebal dan kasar.

Persentase kandungan karbohidrat dari kedua jenis rumput laut yang diamati selama masa pemeliharaan dengan budidaya metode long-line berkisar antara 22,09-31,27\% ( $K$. alvarezii) dan $21,38-24,57 \%$ (G. gigas) dalam bobot kering (Gambar 3). Kandungan karbohidrat pada kedua spesies rumput laut tersebut meningkat dengan bertambahnya umur pemeliharaan. Pada beberapa spesies dari alga merah (Rhodophyta) yang diambil dari ekosistem alami di perairan Sunderban, India memiliki kandungan karbohidrat yang berkisar antara 14,34-28,96\% (Chakraborty \& Santra, 2008). Fleurence (1999) in Chakraborty \& Bhattacharya (2012) menyatakan bahwa kandungan karbohidrat dari berbagai jenis algae sangat bervariasi, di antaranya dapat dipengaruhi oleh perbedaan musim dan stadia pertumbuhannya. Pertumbuhan rumput laut terjadi karena berlangsungnya proses fotosintesis yang menghasilkan karbohidrat sebagai produk akhirnya. Karbohidrat yang dihasilkan dari biomassa rumput laut per luasan area meningkat dengan bertambahnya umur pemeliharaan (Gambar 3), seiring dengan meningkatnya biomassa rumput laut yang dihasilkan per luasan area tersebut. Menurut Diniz et al.(2011) dan Chakraborty \& Bhattacharya (2012), karbohidrat merupakan substansi yang paling besar jumlahnya dalam rumput laut pada umumnya, yang terdapat pada dinding sel (se- perti: agar, selulosa) dan dalam bentuk produk penyimpanan (seperti: pati, laminarin).

Kandungan pigmen yang terdiri atas klorofil-a dan fikoeritrin pada $K$. alvarezii yang dibudidayakan dengan metode long-line secara umum menunjukkan tren peningkatan hingga hari ke-30, kemudian menurun hingga akhir masa pemeliharaan pada hari ke-45 (Gambar 4). Demikian juga kandungan kedua pigmen pada G. gigas yang dibudayakan dengan metode long-line menunjukkan tren peningkatan pada awal budidaya hingga hari ke-10, kemudian menurun pada hari ke-20 dan meningkat kembali pada hari ke-30 (Gambar 4). Packer (2009) menyatakan bahwa efisiensi fotosintesis secara sederhana dapat didefinisikan sebagai persentase radiasi cahaya matahari yang diubah menjadi biomassa. Besarnya radiasi cahaya yang dapat diserap oleh tanaman dipengaruhi juga oleh besarnya kandungan pigmen yang terdapat di dalam kloroplas tanaman. Selain klorofil sebagai pigmen utama, pada rumput laut jenis $K$. alvarezii dan G. gigas terdapat pigmen asesori yang menyerap cahaya pada panjang gelombang yang sedikit berbeda dengan klorofil, yaitu fikoeritrin. Menururt Lakitan (201 1), laju fotosintesis juga dipengaruhi oleh umur atau stadia perkembangan dari organ fotosintesis itu sendiri. Kemampuan organ tersebut untuk berfotosintesis meningkat pada awal perkembangannya, tetapi kemudian mulai menurun, terkadang sebelum organ tersebut berkembang penuh (fully-developed). Organ

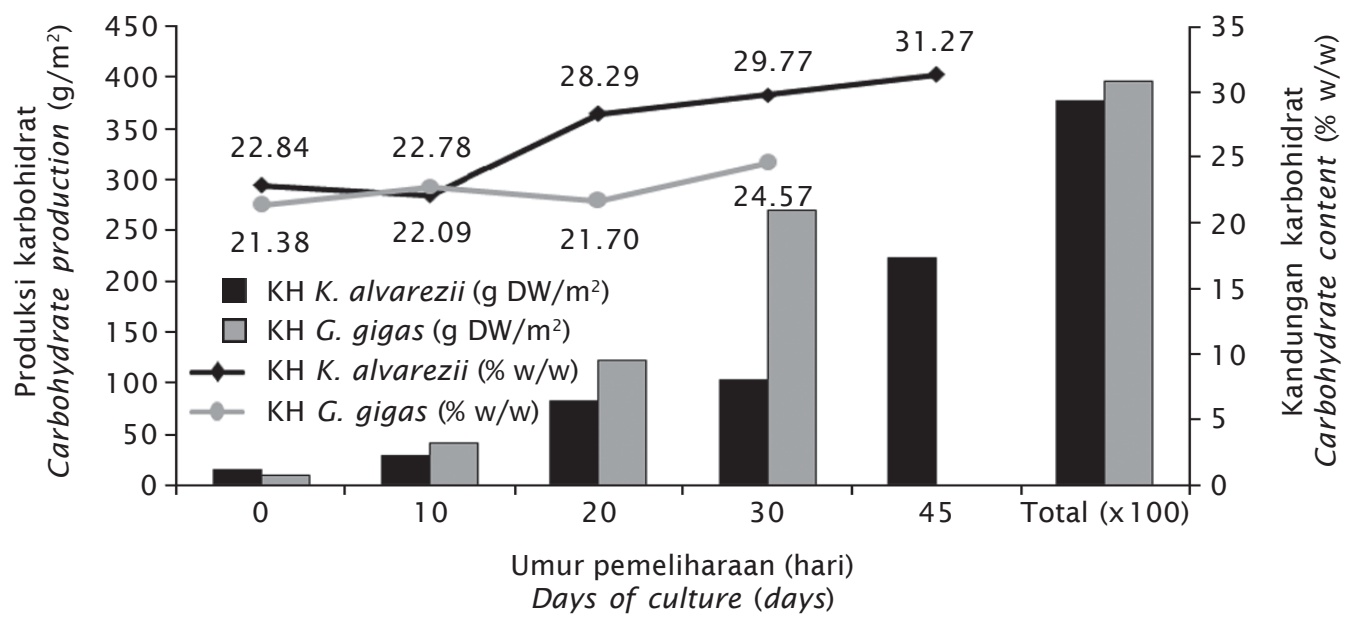

Gambar 3. Produksi dan kandungan karbohidrat dari K. alvarezii dan G. gigas

Figure 3. Carbohydrate content and production of K. alvarezii dan G. gigas 


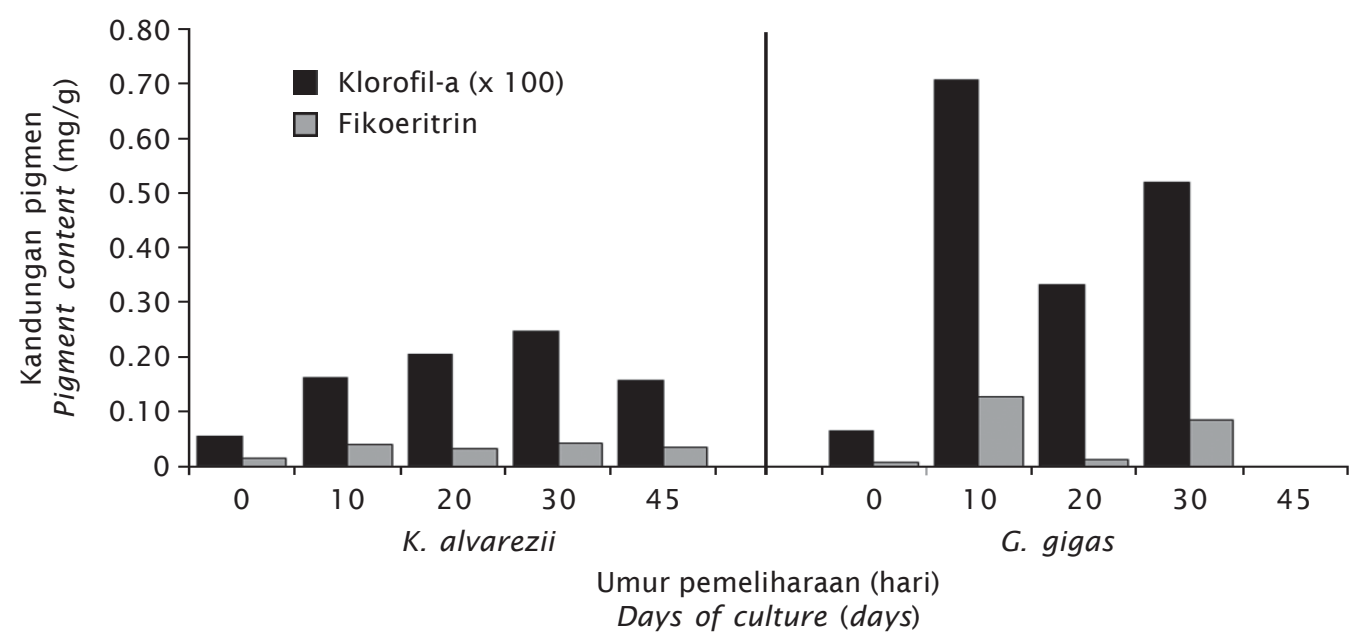

Gambar 4. Kandungan pigmen fotosintesis (klorofil-a dan fikoeritrin) pada K. alvarezii dan G. gigas

Figure 4. Photosynthetic pigment content (chlorophyll-a and phycoerythrin) of K. alvarezii and G. gigas

akan mengalami senescene, yaitu proses penurunan kondisi dan aktivitas metabolisme yang menyertai pertambahan umur yang mengarah pada kematian, organ atau organisme kemudian kehilangan kemampuannya untuk berfotosintesis karena perombakan klorofil dan hilangnya fungsi kloroplas.

Rata-rata indeks percabangan pada G. gigas $(24,07)$ jauh lebih tinggi dibandingkan dengan $K$. alvarezii $(1,86)$ (Tabel 1$)$. Walaupun indeks percabangan pada $K$. alvarezii relatif kecil, tapi spesies ini memiliki 6 (enam) tingkat percabangan, sedangkan pada G. gigas hanya terdapat 3 tingkat percabangan. Namun demikian, G. gigas memiliki jumlah titik percabangan (appical growing point/AGP) yang jauh lebih banyak pada setiap tingkat percabangannya.

Tabel 1. Indeks percabangan rumput laut yang diukur pada akhir masa budidaya

Table 1. Branching index of seaweeds at the end of cultivation

\begin{tabular}{lc}
\hline $\begin{array}{c}\text { Jenis laut } \\
\text { Seaweeds species }\end{array}$ & $\begin{array}{c}\text { Indeks percabangan } \\
\text { Branching index }\end{array}$ \\
\hline K. alvarezii & $1.86+0.58$ \\
G. gigas & $24.07+12.23$ \\
\hline
\end{tabular}

\section{Hubungan Laju Penyerapan Karbon dengan Faktor Internal Rumput Laut dan Parameter Lingkungan Budidaya}

Keberhasilan usaha budidaya rumput laut tidak dapat terlepas dari kondisi lingkungan sekitarnya; terutama kualitas perairan sebagai media yang secara langsung mempengaruhi pertumbuhan rumput laut. Analisis cluster dari laju penyerapan karbon dan faktor internal rumput laut serta parameter lingkungan budidaya, berdasarkan tingkat korelasinya menghasilkan tiga cluster (Gambar 5). Hasil tersebut menunjukkan bahwa laju penyerapan karbon oleh rumput laut berhubungan secara langsung dengan faktor internal rumput laut berupa kandungan klorofil-a, fikoeritrin, dan laju pertumbuhan harian rumput laut, serta faktor eksternal berupa konsentrasi $\mathrm{CO}_{2}$ dan kecerahan perairan dengan korelasi intervariabel sebesar 0,76 (cluster 1). Cluster 2 mewakili parameter yang terdiri dari kandungan karbohidrat rumput laut serta parameter kualitas air yang terdiri dari $\mathrm{NH}_{3}$, tekanan, suhu, konduktivitas, TDS, salinitas, $\mathrm{DO}, \mathrm{pH}$, dan $\mathrm{PO}_{4}-\mathrm{P}$ yang saling berhubungan dengan korelasi intervariabel 0,67 berperan terhadap laju penyerapan karbon. Pada cluster 3 terdapat parameter nitrat yang memiliki hubungan paling jauh dengan laju penyerapan karbon oleh rumput laut, dengan koefisien korelasi 0,37 (Gambar 5). 


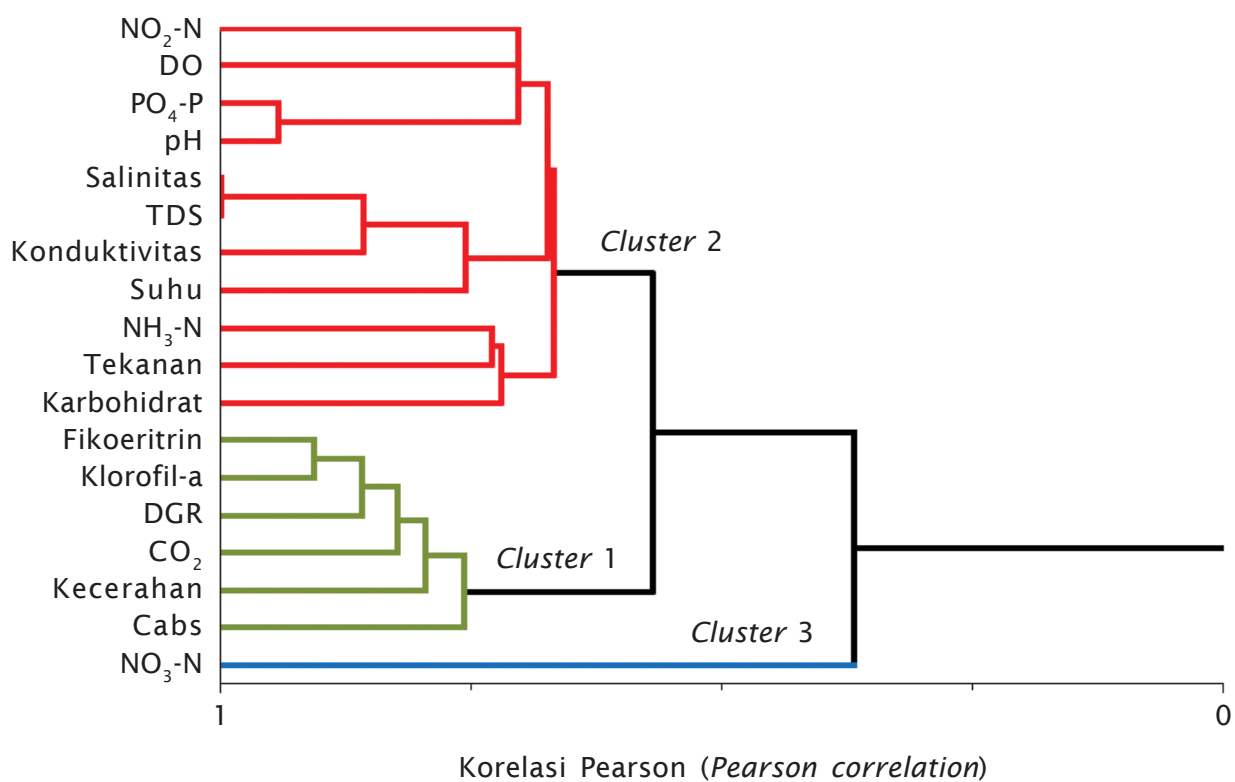

Gambar 5. Dendogram hubungan inter-variabel penyerapan karbon oleh rumput laut dengan parameter yang mempengaruhinya

Figure 5. Dendogram for inter-variable connection of carbon absorption by seaweeds and influential parameters

Packer (2009) menyatakan bahwa efisiensi fotosintesis secara sederhana dapat didefinisikan sebagai persentase radiasi cahaya matahari yang diubah menjadi biomassa. Besarnya radiasi cahaya yang dapat diserap oleh tanaman dipengaruhi juga oleh besarnya kandungan pigmen yang terdapat di dalam kloroplas tanaman. Berdasarkan hasil analisis cluster terhadap parameter lingkungan yang mempengaruhi laju penyerapan karbon, terlihat parameter kandungan nitrat berada pada clusteryang terpisah dengan laju penyerapan karbon oleh rumput laut. Walaupun nitrat merupakan bentuk dari senyawa nitrogen dengan kandungan tertinggi pada air laut, namun nitrat harus melewati dua tahapan proses reduksi untuk menjadi senyawa amonium, sebelum bergabung ke dalam senyawa organik (Granbom et al., 2004). Pada proses asimilasi nitrat, terdapat enzim yang berperan dalam mempercepat fase reduksi nitrat menjadi nitrit, di mana fase ini dianggap sebagai fase pembatas dalam proses konversi nitrat menjadi amonium (Crawford et al., 1986). Enzim tersebut adalah nitrat reduktase. Hasil penelitian Granbom et al. (2004) menunjukkan bahwa aktivitas maksimum enzim nitrat reduktase pada spesies $K$. alvarezii dicapai pada $\mathrm{pH} 8,0$; menurun $10 \%$ pada $\mathrm{pH} 7,5$; sedangkan pada $\mathrm{pH} 7,0$ dan 8,5 aktivitas enzim tesebut masih di atas $60 \%$. pH perairan Teluk Gerupuk pada saat penelitian berkisar antara 7,86-8, 11 (rata-rata 7,92 $\pm 0,097$ ).

Hasil analisis komponen utama (PCA) mengekstrak dua komponen utama pertama yang memiliki eigenvalue lebih besar dari satu dan memiliki nilai ragam kumulatif lebih dari 70\%; yaitu PC1 (39,19\%) dan PC2 (34,62\%) dengan ragam kumulatif 73,81\% (Gambar 6). Berdasarkan korelasi variabel data awal dengan komponen utama (component loadings), dapat digambarkan bahwa karakteristik PC1 dibangun oleh variabel laju penyerapan karbon, laju pertumbuhan harian, klorofil-a dan fikoeritrin dari rumput laut, serta kecerahan, suhu, dan konduktivitas perairan. Karakteristik PC2 dibangun oleh variabel lingkungan yaitu DO, salinitas, TDS, $\mathrm{PO}_{4}-\mathrm{P}, \mathrm{CO}_{2}, \mathrm{NH}_{3}, \mathrm{NO}_{2}$ serta kandungan karbohidrat dari rumput laut. Sedangkan dua variabel lingkungan yaitu $\mathrm{NO}_{3}$ dan tekanan air berada pada PC3 dengan korelasi yang rendah.

Koefisien korelasi mengindikasikan tingkat keeratan hubungan antara laju penyerapan karbon oleh rumput laut dengan variabel- 


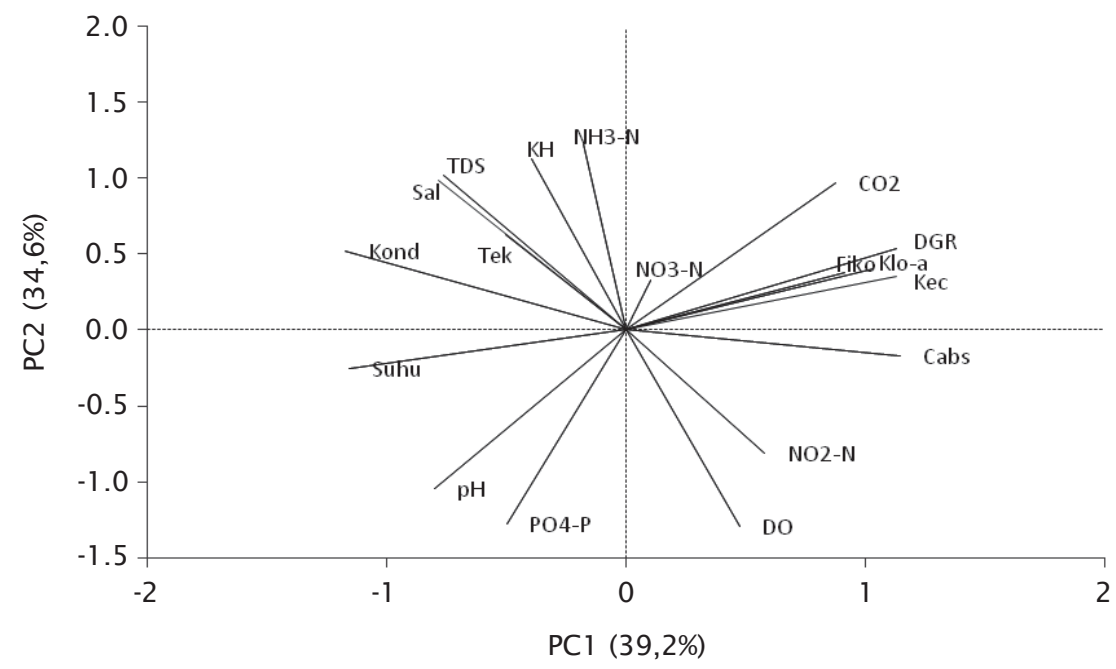

Gambar 6. Loading plot dari dua komponen utama pertama yang menjelaskan $73,81 \%$ dari keragaman total data

Figure 6. Loading plot of the first two principal components that explained $73,81 \%$ of total variance

variabel yang mempengaruhinya, serta muatan dari hubungan yang terbentuk (Gambar 7). Variabel-variabel yang memiliki korelasi positif dengan laju penyerapan karbon yaitu laju pertumbuhan harian, kandungan pigmen klorofil-a dan fikoeritrin rumput laut, serta DO, $\mathrm{NO}_{3}-\mathrm{N}, \mathrm{NO}_{2}-\mathrm{N}, \mathrm{CO}_{2}$, dan kecerahan perairan. Berdasarkan nilai koefisien korelasinya, empat variabel memiliki hubungan korelasi yang tinggi dengan laju penyerapan karbon oleh rumput laut, yaitu laju pertumbuhan harian $(0,7413)$, kandungan klorofil-a $(0,7571)$, kandungan fikoeritrin $(0,7104)$, serta kecerahan perairan $(0,5053)$.

Variabel-variabel yang berkorelasi negatif dengan laju penyerapan karbon oleh rumput laut yaitu kadar karbohidrat rumput laut dan parameter-parameter kualitas air yang terdiri atas suhu, konduktivitas, TDS, salinitas, $\mathrm{pH}$, tekanan, $\mathrm{NH}_{3}-\mathrm{N}, \mathrm{PO}_{4}-\mathrm{P}$ (Gambar 7). Di antara variabel-variabel tersebut terdapat lima variabel yang memiliki nilai korelasi yang tinggi yaitu suhu $(-0,5518)$, konduktivitas $(-0,7209)$, TDS $(-0,5940)$, salinitas $(-5,940)$ dan tekanan $(-0,6486)$.

Berdasarkan hasil analisis statistik di atas dapat diekstrak dua parameter utama dari kualitas lingkungan perairan yang paling berpengaruh terhadap laju penyerapan karbon oleh rumput yang dibudidayakan dengan me- tode long-line di perairan Teluk Gerupuk, Lombok Tengah; yaitu konsentrasi $\mathrm{CO}_{2}$ dan kecerahan perairan. Selain itu, juga terdapat dua faktor internal utama dari rumput laut sendiri yang juga sangat berpengaruh terhadap laju penyerapan karbon, yaitu kandungan pigmen dan laju pertumbuhan.

Peningkatan konsentrasi $\mathrm{CO}_{2}$ di atmosfer diperkirakan akan menyebabkan peningkatan proporsionalitas secara linear terhadap konsentrasi $\mathrm{CO}_{2}$ terlarut pada air permukaan laut sebagai akibat dari pertukaran gas yang berlangsung terus-menerus antara udara dan air laut (Stumm \& Morgan, 1981 in Zou, 2005; Takahashi et al., 1997). Respon jangka panjang dari peningkatan $\mathrm{CO}_{2}$ terhadap fotosintesis dan pertumbuhan tergantung pada ketersediaan nutrien mineral dan cara bagaimana nutrien tersebut digunakan oleh tanaman (Stitt \& Krapp, 1999), karena laju pertumbuhan yang lebih tinggi dengan tingginya konsentrasi $\mathrm{CO}_{2}$, akan meningkatkan kebutuhan nutrien mineral. Dengan demikian, untuk mencapai produksi yang optimal dengan besarnya ketersediaan $\mathrm{CO}_{2}$, maka budidaya rumput laut seharusnya dilakukan pada lokasi dengan ketersediaan nutrien yang cukup. Hal ini dapat dipenuhi dengan penggunaan nutrien yang lebih efisiensi dan atau dengan meningkatkan laju penyerapan dan asimilasi nutrien tersebut oleh tanaman (Zou, 2005). Upaya penyediaan 


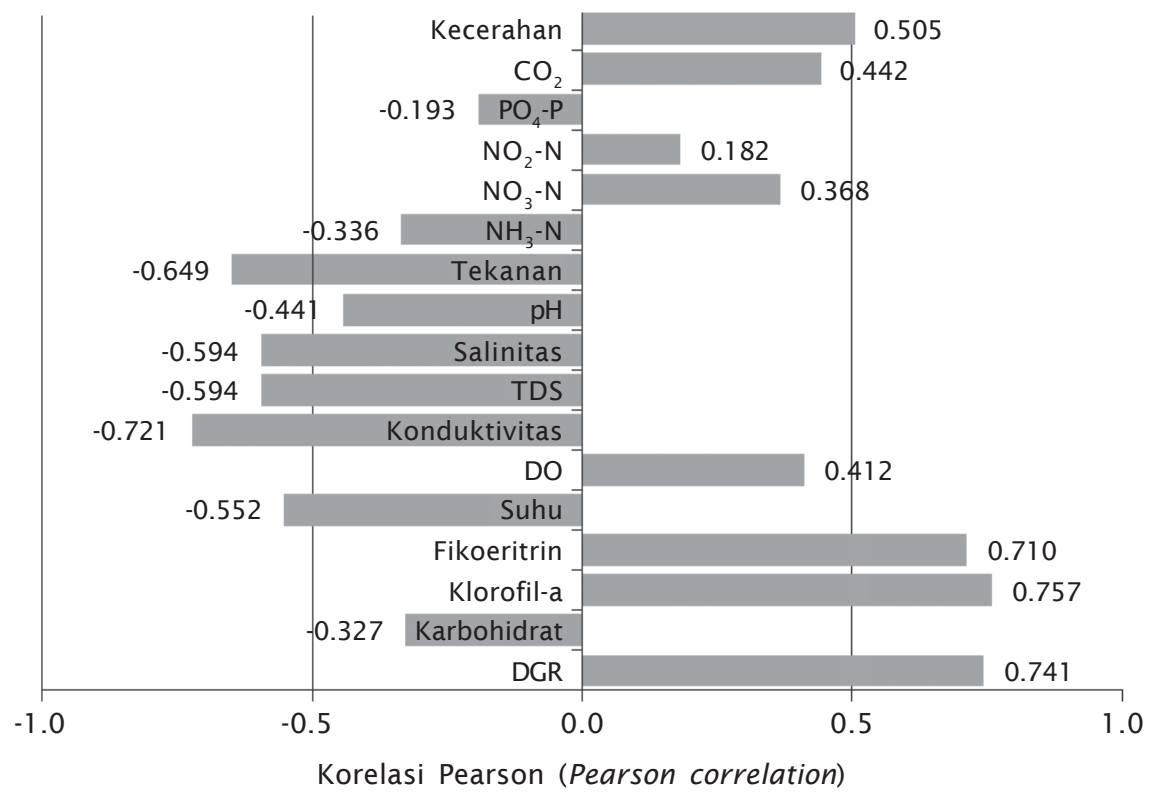

Gambar 7. Nilai korelasi antara laju penyerapan karbon oleh rumput laut dengan variabel-variabel yang mempengaruhinya

Figure 7. Correlation value between carbon absorption rate of seaweed and influential variables

nutrien untuk pertumbuhan rumput laut terkait tingginya ketersediaan $\mathrm{CO}_{2}$ ini dapat diaplikasikan dengan cara mengintegrasikan budidaya rumput laut dengan budidaya ikan dan organisme akuatik lainnya pada lokasi perairan yang sama. Sistem pengembangan budidaya dengan sistem ini sudah mulai populer dengan istilah Integrated Multi-trophic Aquaculture (IMTA).

\section{Potensi Penyerapan Karbon pada Kawasan Budidaya Rumput Laut}

Berdasarkan data kandungan karbon dari kedua spesies rumput laut yang diteliti dan luasan area budidaya rumput laut di perairan Teluk Gerupuk, Lombok; maka dapat dilakukan estimasi jumlah serapan karbon berbasis biomassa rumput laut hasil budidaya yang pada perairan tersebut. Menurut Radiarta $\&$ Rasidi (2012), dari total luasan perairan Teluk Gerupuk yaitu 834 hektar, luas area yang dapat dimanfaatkan sebagai lokasi budidaya rumput laut adalah 322 hektar. Dengan demikian potensi perairan Teluk Gerupuk dalam penyerapan karbon melalui kegiatan budidaya rumput laut diestimasi mencapai 6.656,51 ton karbon per tahun jika komoditas budidaya yang di- kembangkan hanya $K$. alvarezii, sedangkan jika komoditas yang dibudidayakan adalah $G$. gigas, potensi penyerapan karbon oleh kegiatan budidaya rumput laut di perairan Teluk Gerupuk mencapai 29.008,53 ton karbon/tahun.

Laju penyerapan karbon oleh $K$. alvarezii dan G. gigas yang dibudidayakan dengan metode long-line di perairan selatan Pulau Lombok ini relatif besar jika dibandingkan dengan beberapa spesies rumput laut yang hidup secara alami di perairan pantai di Jepang berdasarkan hasil penelitian Muraoka (2004); yaitu 32,38 ton C/ha/tahun (Laminaria sp., Phaeophyta); 8,71 ton $\mathrm{C} /$ ha/tahun (Ecklonia sp., Phaeophyta);4,04 ton C/ha/tahun (Sargassum sp., Phaeophyta); sebesar 0,89 ton C/ha/ tahun (Gelidium sp., Rhodophyta); dan berbagai spesies lainnya sebesar 1,67 ton C/ha/tahun .

Ritschard (1992) menyatakan bahwa, diperlukan langkah-langkah inovatif dalam tindakan mitigasi terhadap peningkatan emisi $\mathrm{CO}_{2}$. Inovasi yang paling praktis yang disebutkan adalah dengan meningkatkan penyerapan $\mathrm{CO}_{2}$ melalui proses fotosintesis yang mencakup peningkatan penyimpanan karbon dalam biomassa hutan, substitusi bahan bakar 
fosil dengan biofuel, peningkatan penyerapan karbon oleh tanah, dan peningkatan produktivitas primer ekosistem laut. Namun dari setiap metode tersebut masih terdapat pertanyaan yang belum terjawab tentang kelayakan teknis dan ekonomisnya sekaligus konsekuensi lingkungan yang dapat ditimbulkan.

Pengembangan budidaya rumput laut dapat menjadi salah satu metode inovatif di antara langkah-langkah yang dibutuhkan dalam upaya mitigasi terhadap berlangsungnya proses pemanasan global, di mana aktivitas budidaya rumput laut dapat mereduksi keberadaaan gas $\mathrm{CO}_{2}$ di atmosfir dalam kuantitas yang cukup besar. Besarnya potensi ekosistem pantai untuk pengembangan usaha budidaya rumput laut, memberikan peluang yang juga semakin besar dalam penyerapan karbon oleh rumput laut berbasis budidaya. Selain itu, aktivitas budidaya rumput laut juga menjawab kebutuhanakan kelayakan teknis, maupun ekonomis, serta memberikan kontribusi positif terhadap pengendalian pencemaran organik di lingkungan perairan.

\section{KESIMPULAN DAN SARAN}

\section{Kesimpulan}

Hasil penelitian ini dapat disimpulkan bahwa kemampuan G. gigas dalam menyerap karbon mencapai 335\% lebih tinggi dibandingkan $K$. alvarezii. Laju penyerapan karbon oleh rumput laut memiliki korelasi positif tertinggi dengan faktor internal rumput laut yaitu kandungan pigmen, dan faktor eksternalnya yaitu kecerahan perairan. Potensi penyerapan karbon oleh kawasan budidaya rumput laut Teluk Gerupuk dengan luas area budidaya potensial 322 hektar mencapai 6.656,51 ton karbon/tahun untuk komoditas budidaya K. alvarezii dan 29.008,53 ton C/tahun untuk komoditas budidaya G. gigas. Strategi pengelolaan budidaya rumput laut dapat disesuaikan berdasarkan segmen umur dengan laju penyerapan karbon tertinggi, yaitu pada umur pemeliharaan 0-20 hari yang dapat diaplikasikan dengan cara melakukan peremajaan, sehingga lebih efektif dalam penyerapan karbon dari lingkungan dan peningkatan produktivitas budidaya rumput laut.

\section{Saran}

Agar penyerapan karbon oleh rumput laut lebih tinggi, maka akan lebih baik lagi jika lo- kasi budidaya rumput laut diintegrasikan dengan lokasi budidaya ikan, sehingga limbah budidaya ikan dapat dimanfaatkan sebagai sumber nutrien oleh rumput laut. Dalam hal ini, ketersediaan nutrien berperan dalam proses asimilasi $\mathrm{CO}_{2}$ dan pertumbuhan pada rumput laut.

\section{UCAPAN TERIMA KASIH}

Penulis mengucapkan terima kasih kepada Balai Budidaya Laut Lombok atas bantuan dan fasilitas selama penelitian di lapangan. Kami juga mengucapkan terima kasih kepada Dr. Anang Hari Kristanto, Dr. I Nyoman Radiarta, Dr. Ketut Sugama, dan Dr. Idil Ardi, yang telah membantu kelancaran pengumpulan data lapangan. Penelitian ini merupakan bagian dari penelitian Kajian Dampak Pemanasan Global terhadap Perikanan Budidaya pada Pusat Penelitian dan Pengembangan Perikanan Budidaya Tahun Anggaran 2012.

\section{DAFTAR ACUAN}

Aldrian, E., Karmini, M., \& Budiman. 2011. Adaptasi dan mitigasi perubahan iklim di Indonesia. Pusat Perubahan Iklim dan Kualitas Udara, Kedeputian Bidang Klimatologi. Badan Meteorologi, Klimatologi, dan Geofisika (BMKG). Jakarta, $178 \mathrm{hlm}$.

Chakraborty, S. \& Bhattacharya, T. 2012. Nutrient composition of marine benthic algae found in the Gulf of Kutch coastline, Gujarat, India. J. Algal Biomass Utilization, 3(1): 3238.

Chakraborty, S. \& Santra, S.C. 2008. Biochemical composition of eight benthic algae collected from Sunderban. Indian Journal of Marine Science, 37(3): 329-332.

Crawford, N.M., Campbellt, W.H., \& Davis, R.W. 1986. Nitrate reductase from squash: cdna cloning and nitrate regulation. Proc. Natl. Acad. Sci., (83): 8,073-8,076.

Diniz, G.S., Barbarino, E., Oiano-Neto, J., Pacheco, S., \& Lourenço, S.O. 2011 . Gross chemical profile and calculation of nitrogen-to-protein conversion factors for five tropical seaweeds. American Journal of Plant Sciences, 2: 287-296.

Granbom, M., Chow, F., Lopes, P.F., De Oliveira, M.C., Colepicolo, P., De Paula, E.J., \& Pedersén, M. 2004. Characterisation of nitrate reductase in the marine macroalga Kappaphycus alvarezii (Rhodophyta). Aquatic Botany, 78: 295-305. 
[IPCC] Intergovernmental Panel on Climate Change. 2007. Climate change 2007: synthesis report.In: Allali, A., Bojariu, R., Diaz, S., Elgizouli, I., Griggs, D., Hawkins, D., Hohmeyer, O., Jallow, B.P., Kajfez-Bogataj, L., Leary, N., Lee, H., Wratt, D. (eds.). The Working Group contributions to the Fourth Assessment Report. IPCC Plenary XXVII, Valencia, Spain, 12-17 November 2007, 73 pp.

Kaladharan, P., Veena, S., \& Vivekanandan, E. 2009. Carbon sequestration by a few marine algae: Observation and projection. Journal of the Marine Biological Association of India, 51 (1): 107-1 10.

KKP (Kementerian Kelautan dan Perikanan). 2011 . Kelautan dan perikanan dalam angka 2011 . Pusat Data Statistik dan Informasi. Kementerian Kelautan dan Perikanan, 120 hlm.

Lakitan B. 2011 . Dasar-dasar fisiologi tumbuhan. Rajawali Pers. Jakarta, 206 hlm.

Lüning, K. 1990. Seaweed: Their Environment, Biogeography, And Ecophysiology. John Wiley \& Sons, Inc. Canada, $527 \mathrm{hlm}$.

Muraoka, D. 2004. Seaweed resources as a source of carbon fixation. Bull. Fish. Res. Agen. Supplement No. 1, p. 59-63.

Naguit, M.R.A. \& Tisera, W.L. 2009. Pigment analysis on Eucheuma denticulatum (Collins \& Hervey) and Kappaphycus alvarezii (Doty) cultivars cultured at different depths. The Treshold, IV: 29-37.

Nellemann, C., Corcoran, E., Duarte, C.M., Valdés, L., De Young, C., Fonseca, L., \& Grimsditch, G. (eds.). 2009. Blue carbon: the role of healthy oceans in binding carbon. A Rapid Response Assessment. United Nations Environment Programme, GRID-Arendal. Birkeland Trykkeri AS, Norway, $78 \mathrm{pp}$.

Packer, M. 2009. Algal capture of carbon dioxide: biomass generation as a tool for green- house gas mitigation with reference to New Zealand energy strategy and policy. Energy Policy, 37: 3,428-3,437.

Pickering, T.D., Gordon, M.E., \& Tong, L.J. 1995. A preliminary trial of a spray culture technique for growing the agarophyte Gracilaria chilensis (Gracilariales, Rhodophyta). Aquaculture, 13: 43-49.

Radiarta, I N. \& Rasidi. 2012. Analisa spasial kondisi kualitas perairan untuk mendukung budidaya rumput laut di Teluk Gerupuk Kabupaten Lombok Tengah Provinsi Nusa Tenggara Barat. Prosiding Seminar Nasional Perikanan Indonesia 2012, Sekolah Tinggi Perikanan. Jakarta, hlm. 88-94.

Ritschard, R.L. 1992. Marine algae as a $\mathrm{CO}_{2}$ sink. Water, Air, and Soil Pollution 64, p. 289-303.

Stewart, H.L. \& Carpenter, R.C. 2003. The effecs of morphology and water flow on photosynthesis of marine macroalgae. Ecology, 84(1 1): 2,999-3,012.

Stitt, M. \& Krapp, A. 1999. The interaction between elevated carbon dioxide and nitrogen nutrient: the physiological and molecular background. Plant Cell Environ, (22): 583-621.

Takahashi, T., Feely, R.A., Weiss, R.F., Wanninkhof, R.H., Chipman, D.W., Sutherland, S.C., \& Timothy, T.T. 1997. Global air-sea flux of $\mathrm{CO}_{2}$ : An estimate based on measurements of sea-air $\mathrm{pCO}_{2}$ difference. Proc. Natl. Acad. Sci., (94): 8,292$8,299$.

Thirumaran, G. \& Anantharaman, P. 2009. Daily Growth Rate of Field Farming Seaweed Kappaphycus alvarezii (Doty) Doty ex P. Silva in Vellar Estuary. World Journal of Fish and Marine Sciences, 1(3): 144-153.

Zou, D. 2005 . Effects of elevated atmospheric $\mathrm{CO}_{2}$ on growth, photosynthesis and nitrogen metabolism in the economic brown seaweed, Hizikia fusiforme (Sargassaceae, Phaeophyta). Aquaculture, 250: 726-735. 